\title{
Sazetidine-A Activates and Desensitizes Native $\alpha 7$ Nicotinic Acetylcholine Receptors
}

\author{
Jack L. Brown · Susan Wonnacott
}

Received: 26 February 2014/Revised: 24 March 2014/Accepted: 1 April 2014/Published online: 12 April 2014

(C) The Author(s) 2014. This article is published with open access at Springerlink.com

\begin{abstract}
The aim of this study was to investigate the ability of sazetidine-A, a novel partial agonist at $\alpha 4 \beta 2$ nicotinic acetylcholine receptors (nAChRs), to affect the function of native $\alpha 7 \mathrm{nAChRs}$ in SH-SY5Y cells and primary cortical cultures. The $\alpha 7$-selective positive allosteric modulator PNU-120596 was used to reveal receptor activation, measured as an increase in intracellular calcium using fluorescent indicators. In the absence of PNU-120596, sazetidine-A elicited mecamylamine-sensitive increases in fluorescence in SH-SY5Y cells $\left(\mathrm{EC}_{50} 4.2 \mu \mathrm{M}\right)$ but no responses from primary cortical neurons. In the presence on PNU-120596, an additional response to sazetidine-A was observed in SH-SY5Y cells $\left(\mathrm{EC}_{50} 0.4 \mu \mathrm{M}\right)$ and robust responses were recorded in $14 \%$ of cortical neurons. These PNU-120596-dependent responses were blocked by methyllycaconitine, consistent with the activation of $\alpha 7 \mathrm{nAChRs}$. Preincubtion with sazetidine-A concentration-dependently attenuated subsequent responses to the $\alpha 7$-selective agonist PNU-282987 in SH-SY5Y cells ( IC $\left._{50} 476 \mathrm{nM}\right)$ and cortical cultures. These findings support the ability of sazetidine-A to interact with $\alpha 7 \mathrm{nAChRs}$, which may contribute to sazetidine-A's actions in complex physiological systems.
\end{abstract}

Keywords Live cell calcium imaging - SH-SY5Y cells · Primary cortical neurons · PNU-120596

Sazetidine-A (6-[5-[(2S)-2-azetidinylmethoxy]-3-pyridinyl]5-hexyn-1-ol) has the profile of a potent partial agonist at $\alpha 4 \beta 2$

Special Issue: In honor of Lynn Wecker.

J. L. Brown · S. Wonnacott $(\bowtie)$

Department of Biology and Biochemistry, University of Bath, Bath BA2 7AY, UK

e-mail: s.wonnacott@bath.ac.uk; bsssw@bath.ac.uk nicotinic acetylcholine receptors (nAChRs) and has attracted interest as a lead compound for several therapeutic targets, making detailed knowledge of its wider activity an important consideration. Sazetidine-A is a derivative of the nicotinic agonist A-85380, developed to bear a long side chain for potential attachment of fluorescent or photoaffinity probes [1]. In binding assays it showed improved selectivity for $\alpha 4 \beta 2$ nAChRs, compared with A-85380, with $\mathrm{K}_{\mathrm{i}}$ values of 0.4 and $0.6 \mathrm{nM}$ for rat and human $\alpha 4 \beta 2 \mathrm{nAChRs}$ respectively.

In contrast to the parent molecule, sazetidine-A appeared to be devoid of agonist activity at recombinant human $\alpha 4 \beta 2$ nAChRs and was described as a 'silent desensitizer' [1]. Subsequent studies revealed sazetidine-A to be a stoichiometry-dependent agonist capable of fully activating high sensitivity human $\alpha 4_{2} \beta 2_{3}$ (HS- $\alpha 4_{2} \beta 2_{3}$ ) nAChRs, whereas it had negligible efficacy, relative to acetylcholine, at lower sensitivity $\alpha 4_{3} \beta 2_{2}$ (LS- $\left.\alpha 4_{3} \beta 2_{2}\right)$ nAChRs [2,3]. Presumably the stable cell lines employed in the original study predominantly expressed the low sensitivity form. The 'accessory' subunit occupying the fifth position in the pentameric nAChR, a position that does not directly contribute to either of the two high affinity, orthosteric agonist binding sites, nevertheless can influence receptor properties [4]. In this case the subunit occupying this position appears to determine the ability of sazetidineA to affect the opening of the $\alpha 4 \beta 2 \mathrm{nAChR}$ channel. This notion is reinforced by the opposing effects of $\alpha 5$ and $\beta 3$ subunits in the fifth position: inclusion of an $\alpha 5$ subunit to form $\alpha 4_{2} \beta 2_{2} \alpha 5 \mathrm{nAChRs}$ abolished agonist efficacy [5], whereas sazetidine- $\mathrm{A}$ is a potent and efficacious agonist at $\alpha 4 \alpha 6 \beta 2_{2} \beta 3 \mathrm{nAChRs}\left(\mathrm{EC}_{50} 19 \mathrm{nM}\right)[6]$.

The sobriquet 'silent desensitizer' reflected the observation that a brief preincubation with $1 \mu \mathrm{M}$ sazetidine-A induced a long lasting inhibition of recombinant human $\alpha 4 \beta 2$ nAChRs expressed in SH-EP1 cells $\left(\mathrm{IC}_{50}\right.$ 
value $\sim 30 \mathrm{nM}$ ), compared with the rapid recovery following preincubation with nicotine [1]. More recent studies that have taken into account its differential interaction with the two stoichiometries of $\alpha 4 \beta 2 \mathrm{nAChRs}$ have shown that sazetidine-A selectively desensitizes HS- $\alpha 4_{2} \beta 2_{3}$ nAChRs over LS- $\alpha 4_{3} \beta 2_{2}[7,8]$.

Its partial agonist profile has raised interest in sazetidine-A as a therapeutic lead for numerous indications, including drug dependence $[9,10]$, cognitive and attentional deficits [11], pain [12] and depression [13]. Given the complex contributions of multiple nAChRs in the CNS to brain function and behaviours, it is important to understand the specificty of agents such as sazetidine-A. It binds with much lower affinity but acts as a full or substantial agonist at recombinant $\alpha 4 \beta 4, \alpha 3 \beta 4$, and $\alpha 6 \beta 2 *$ nAChRs [1, 6, 7]. Sazetidine-A's activation of $\alpha 7$ nAChRs has only recently been documented, with very different $\mathrm{EC}_{50}$ values and efficacies at human $(1.2 \mu \mathrm{M}$; $100 \%)$ and rat $(60 \mu \mathrm{M} ; 6 \%) \alpha 7 \mathrm{nAChRs}[7,14]$. The contribution of $\alpha 7 \mathrm{nAChRs}$ to the clinical targets mentioned above [15, 16], as well as $\alpha 7 \mathrm{nAChRs}$ credited with functions in peripheral systems that could mediate sideefffects [17] suggest that this nAChR subtype, in particular, merits further attention. Hitherto, sazetidine-A's activation of native $\alpha 7 \mathrm{nAChRs}$ has not been reported. In this study we examined the ability of sazetidine-A to activate and desensitize $\alpha 7 \mathrm{nAChRs}$ in SH-SY5Y cells and primary cortical neurons.

\section{Materials and Methods}

\section{Materials}

Triton X-100, (-)-nicotine hydrogen tartrate and mecamylamine hydrochloride, were purchased from SigmaAldrich (Poole, Dorset, UK); B27, L-glutamine, antibiotics, fluo-3 AM, fura-2 AM, and pluronic f127 were obtained from Life Technologies (Paisley, UK); sazetidine-A dihydrochloride, tetrodotoxin citrate, methyllycaconitine citrate and 5-iodo-A85380 dihydrochloride were purchased from Tocris Bioscience (Avonmouth, UK); PNU-120596 and PNU-282987 were provided by Pfizer Inc. USA; general reagents were purchased from Fisher Scientific (Loughborough, UK).

Methods

\section{SH-SY5Y Cell Culture}

Human neuroblastoma SH-SY5Y cells (ECACC, Salisbury, UK; passages 16-27) were cultured as previously described [18]. In brief, cultures were maintained in
Advanced Dulbecco's modified Eagle's media (DMEM/ F12), supplemented with $2 \%$ fetal bovine serum (FBS), $2 \mathrm{mM}$ L-glutamine, $190 \mathrm{U} / \mathrm{ml}$ penicillin and $0.2 \mathrm{mg} / \mathrm{ml}$ of streptomycin in $94 \times 16 \mathrm{~mm}$ tissue culture dishes in a humidified chamber at $37{ }^{\circ} \mathrm{C}$ with $5 \% \mathrm{CO}_{2}$. Cells were seeded 1:2 into 96-well plates, experiments were performed $72 \mathrm{~h}$ later with confluent cultures.

\section{Mouse Primary Cortical Cultures}

Primary cultures were prepared from embryonic mouse cortices as previously described [19]. Briefly, time-mated pregnant female CD1 mice were killed by cervical dislocation and E18 embryos were harvested. Cortices were dissected in PBS with $30 \%$ glucose $\left(\mathrm{Ca}^{2+}\right.$ and $\mathrm{Mg}^{2+}$ free) and dissociated with a fire polished glass Pasteur pipette. Tissue was centrifuged at $500 \mathrm{~g}$ for $5 \mathrm{~min}$, resuspended in neurobasal medium supplemented with B27, $2 \mathrm{mM}$ L-glutamine and $60 \mu \mathrm{g} / \mathrm{ml}$ penicillin and $100 \mu \mathrm{g} / \mathrm{ml}$ streptomycin (12 ml medium per brain). For live imaging experiments, cells were plated on $25 \mathrm{~mm}$ round glass coverslips (thickness no. 1) coated with $20 \mu \mathrm{g} / \mathrm{ml}$ poly-Dlysine, in 6-well tissue culture plates (Corning, USA). Cells were allowed to grow for 10-14 days in vitro (DIV) at $37{ }^{\circ} \mathrm{C}$ in a humidified atmosphere of $95 \%$ air and $5 \%$ $\mathrm{CO}_{2}$.

$\mathrm{Ca}^{2+}$ Fluorimetry

\section{SH-SY5Y Cells}

Increases in $\left[\mathrm{Ca}^{2+}\right]_{\mathrm{ic}}$ were measured as described previously [20]. Briefly, cells were washed twice with Tyrode's salt solution (TSS: $137 \mathrm{mM} \mathrm{NaCl}, 2.7 \mathrm{mM} \mathrm{KCl}, 1.0 \mathrm{mM}$ $\mathrm{MgCl}_{2}, \quad 1.8 \mathrm{mM} \quad \mathrm{CaCl}_{2}, \quad 0.2 \mathrm{mM} \quad \mathrm{NaH}_{2} \mathrm{PO}_{4}, \quad 12 \mathrm{mM}$ $\mathrm{NaHCO}_{3}, 5.5 \mathrm{mM}$ glucose; $\mathrm{pH}$ 7.4) and incubated with the membrane-permeable, $\mathrm{Ca}^{2+}$ sensitive dye fluo-3 AM $(10 \mu \mathrm{M})$ and $0.02 \%$ pluronic $\mathrm{F} 127$ for $1 \mathrm{~h}$ at room temperature in darkness. Cells were then washed twice with TSS before pre-incubation (10 min) with $80 \mu \mathrm{l}$ antagonists, modulators or TSS. Changes in fluorescence (excitation $485 \mathrm{~nm}$, emission $538 \mathrm{~mm}$ ) were monitored using a Fluoroskan Ascent fluorescent plate reader (Thermo Scientific, UK). Basal fluorescence was measured for $5 \mathrm{~s}$ before agonist $(20 \mu \mathrm{l})$ was added and fluorescence was monitored for a further $20 \mathrm{~s}$. Calibration of responses was achieved by determining the maximum and minimum fluorescence values of each fluo-3 AM signal, by application of $0.2 \%$ Triton X-100 $\left(\mathrm{F}_{\max }\right)$ followed by $40 \mathrm{mM} \mathrm{MnCl}_{2}\left(\mathrm{~F}_{\min }\right)$. Data were calculated as a percentage of $F_{\max }-F_{\min }$. Concentration response data were fitted to the Hill equation and half maximal effective concentrations determined. 


\section{Cortical Cultures}

Changes in $\left[\mathrm{Ca}^{2+}\right]_{\mathrm{ic}}$ in individual cells of mouse E18 cortical cultures grown on glass coverslips were monitored using live cell imaging (Concord System, Perkin Elmer, UK). Cortical cultures (10-14 DIV) were washed twice with calcium buffer $(140 \mathrm{mM} \mathrm{NaCl}, 5.0 \mathrm{mM} \mathrm{KCl}, 1.0 \mathrm{mM} \mathrm{MgCl}, 1.8 \mathrm{mM}$ $\mathrm{CaCl}_{2}, 10 \mathrm{mM}$ glucose, $5.0 \mathrm{mM}$ HEPES; $\mathrm{pH} 7.4$ ) and incubated with the ratiometric $\mathrm{Ca}^{2+}$-sensitive dye fura-2 AM $(5 \mu \mathrm{M})$ and $0.02 \%$ pluronic $\mathrm{F} 127$ for $1.5 \mathrm{~h}$ at room temperature in darkness. After another two washes with buffer, coverslips were assembled into a temperature controlled $\left(37{ }^{\circ} \mathrm{C}\right.$ ) perfusion chamber (Series $20 \mathrm{PH} 2$ platform with a RC-21BR chamber, Harvard Apparatus, MA, USA) and mounted on an inverted fluorescence microscope. Buffer and drug solutions were pre-heated to $37{ }^{\circ} \mathrm{C}$ and perfused at a rate of $5 \mathrm{ml} / \mathrm{min}$. Fura-2 AM was excited at 340 and $380 \mathrm{~nm}$ using a SpectroMaster I and emissions at $510 \mathrm{~nm}$ were detected with an intensified Ultrapix PDCI low light level CCD camera. All experiments were carried out in the presence of $1 \mu \mathrm{M}$ tetrodotoxin (TTX) pre-incubated for at least $1 \mathrm{~min}$ prior to recording. During long drug pre-incubations perfusion was switched off to reduce drug use, and recording was turned off to prevent photobleaching.

Data were analysed with Ultraview software (Perkin Elmer, UK) and expressed as a ratio of $\mathrm{F}_{340}: \mathrm{F}_{380}$ following subtraction of background fluorescence taken from a region in which no cells could be seen. For successive drug treatments on the same cells, initial peak $\mathrm{F}_{340}: \mathrm{F}_{380}$ ratio for each individual responding region of interest (ROI) was normalized to $100 \%$ following subtraction of mean basal $\mathrm{F}_{340}: \mathrm{F}_{380}$ ratio recorded immediately before drug application. Subsequent responses in the presence of antagonists/modulators or after washout were calculated as a percentage of the original response from the same ROI. These values were then averaged within experiments, such that $\mathrm{n}$ values reflect the number of independent cultures examined.

\section{Statistical Analysis}

Statistical significance was evaluated by ANOVA with post-hoc test, or $t$-test as appropriate, with details given in figure legends.

\section{Results}

Effects of Sazetidine-A on $\mathrm{Ca}^{2+}$ Responses Initiated by Native Human nAChRs Expressed in SH-SY5Y Cells

SH-SY5Y cells express $\alpha 3, \alpha 5, \alpha 7, \beta 2$, and $\beta 4 \mathrm{nAChR}$ subunits [21-23] consistent with the formation of functional $\alpha 3 *$ and $\alpha 7 \mathrm{nAChRs}$ [20]. Based on the sensitivities of recombinant non- $\alpha 4 \beta 2$ nAChRs, sazetidine-A was examined at 10 and $100 \mu \mathrm{M}$ in SH-SY5Y cells loaded with the $\mathrm{Ca}^{2+}$ indicator fluo-3 AM. Both concentrations of sazetidine-A produced a similar increase in fluorescence and this response was abolished in the presence of $30 \mu \mathrm{M}$ mecamylamine (Fig. 1). The $\alpha 7$-selective antagonist methyllycaconitine (MLA; $100 \mathrm{nM}$ ) was without effect. This suggests that under the conditions of the assay, sazetidine-A activates $\alpha 3$-containing nAChRs but not $\alpha 7$ nAChRs, consistent with previous findings for other agonists [24]. However, in the presence of the $\alpha 7$-selective positive allosteric modulator (PAM) PNU-120596 (10 $\mu \mathrm{M})$ [25], sazetidine-A evoked significantly larger increases in fluorescence that were partially blocked by both mecamylamine and by MLA (Fig. 1). This suggests that PNU120596 reveals an $\alpha 7 \mathrm{nAChR}$-mediated increase in intracellular $\mathrm{Ca}^{2+}$.

The response elicited by $10 \mu \mathrm{M}$ sazetidine-A in the presence of PNU-120596 (2.3 \pm 0.7 fold increase in fluorescence, Fig. 1) is comparable to that observed with the structurally related agonist 5-iodo-A85380 $(1 \mu \mathrm{M}$; $2.3 \pm 0.2$ fold increase) and with nicotine $(30 \mu \mathrm{M}$; $4.0 \pm 0.2$ fold increase), both tested in the presence of the PAM (data not shown). Increases in fluorescence in response to sazetidine-A were concentration dependent (Fig. 2). The concentration response curve was shifted to the left in the presence of PNU-120596. $\mathrm{EC}_{50}$ values of 4.2 and $0.4 \mu \mathrm{M}$ were derived for sazetidine- $\mathrm{A}$ in the absence and presence of PNU-120596, respectively.

The propensity of sazetidine-A to antagonize nAChRs in SH-SY5Y cells was assessed by preincubating cultures with increasing concentrations of sazetidine-A for $10 \mathrm{~min}$, followed by stimulation with $100 \mu \mathrm{M}$ nicotine (to activate $\alpha 3$-containing nAChRs) or the $\alpha 7$-selective agonist PNU$282987(10 \mu \mathrm{M})$, in the presence of the PAM PNU120596. Maximally effective agonist concentrations were deployed to elicit the optimum signal for quantitating inhibition. In both cases sazetidine-A produced a concentration-dependent inhibition of agonist-evoked responses, with $\mathrm{IC}_{50}$ values of 522 and $476 \mathrm{nM}$ respectively (Fig. 3).

\section{Effects of Sazetidine-A on $\alpha 7$ nAChR-Mediated $\mathrm{Ca}^{2+}$ Signals in Mouse Cortical Neurons}

Experiments were carried out on mouse E18 primary cortical cultures to assess the effects of sazetidine-A on native $\alpha 7 \mathrm{nAChRs}$ in cells with a more neuronal phenotype. Cortical cultures were loaded with fura-2 AM and changes in fluorescence indicative of changes in intracellular $\mathrm{Ca}^{2+}$ were monitored by live cell imaging. Sazetidine-A alone (10 nM-10 $\mu \mathrm{M} ; 20 \mathrm{~s}$ application) failed to evoke any change in fluorescence, except for occasional, inconsistent 


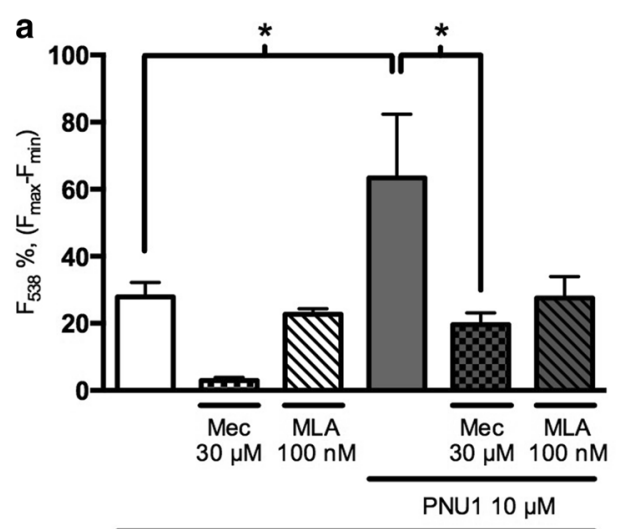

Saz $10 \mu \mathrm{M}$

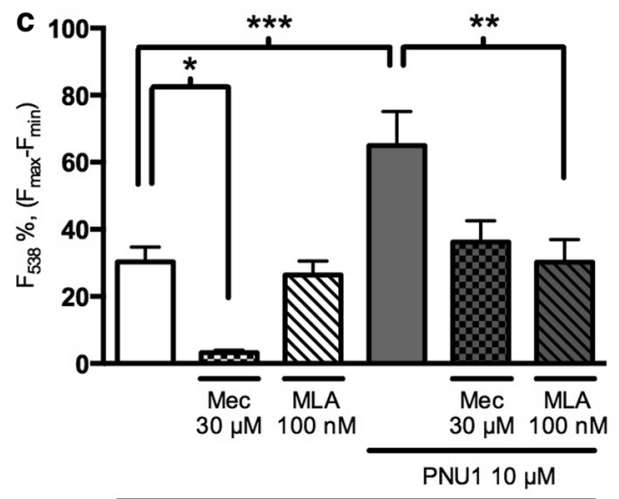

Saz $100 \mu \mathrm{M}$

Fig. 1 Intracellular calcium elevations evoked by sazetidine-A in SH-SY5Y cell populations. SH-SY5Y cells loaded with fluo-3 AM were preincubated for $10 \mathrm{~min}$ with or without antagonist (mecamylamine (Mec), $30 \mu \mathrm{M}$, chequered bars, or MLA, $100 \mathrm{nM}$, crosshatched bars) and/or PNU-120596 (PNU1, $10 \mu \mathrm{M}$, grey bars) before addition of sazetidine-A (Saz, $10 \mu \mathrm{M}, \mathbf{a}, \mathbf{b} ; 100 \mu \mathrm{M}, \mathbf{c}, \mathbf{d})$ in the presence (grey bars) or absence (white bars) of PNU-120596 $(10 \mu \mathrm{M})$. Fluorescence at $538 \mathrm{~nm}$ was monitored for $20 \mathrm{~s}$; representative traces are shown (b, d; some antagonist curves omitted for

increases at the highest concentration tested. In contrast, $40 \mathrm{mM} \mathrm{KCl}$ consistently produced robust responses from a majority of cells (data not shown). Following preincubation with PNU-120596, co-application of $10 \mu \mathrm{M}$ sazetidine-A with the PAM evoked sustained responses from $14 \%$ of cells (average from 6 experiments from 3 independent cultures). Responses were completely blocked by $100 \mathrm{nM}$ MLA, with partial recovery $(32.4 \pm 9.4 \%$ of initial response) following $10 \mathrm{~min}$ washout (Fig. 4).

Sazetidine-A was examined for its ability to attenuate responses from $\alpha 7 \mathrm{nAChRs}$ in cortical neurons by sequential application of the $\alpha 7 \mathrm{nAChR}$ agonist PNU282987 alone (in the presence of PNU-120596) and following exposure to sazetidine-A for $10 \mathrm{~min}$ (Fig. 5). Sazetidine-A applied at $500 \mathrm{nM}$, a concentration approximating the $\mathrm{IC}_{50}$ value derived from SH-SY5Y cells (Fig. 3), decreased the response to PNU-282987 by $59 \%$, b
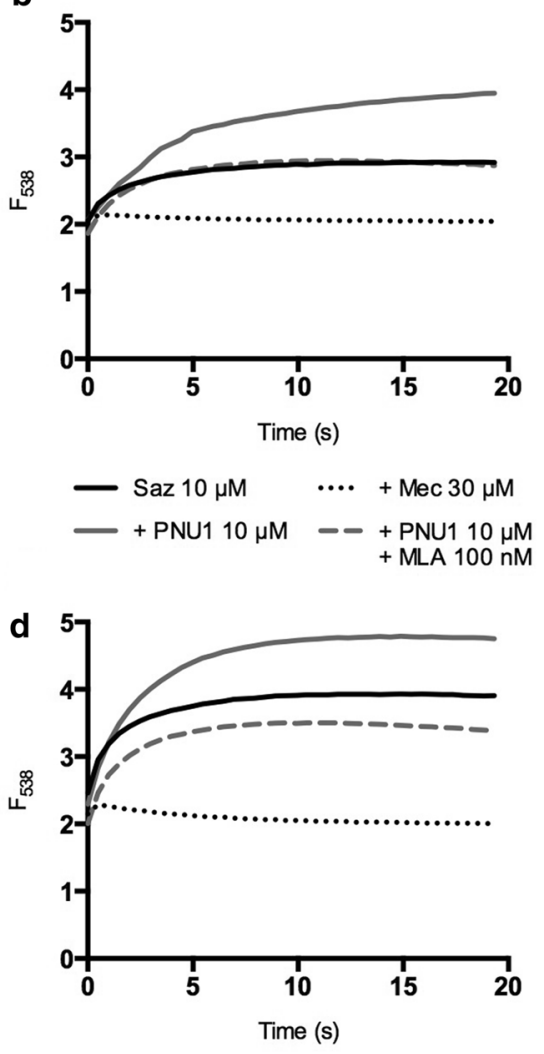

clarity). The increase in fluorescence at $20 \mathrm{~s}$ is presented as a percentage of the maximum fluorescence determined by addition of $0.2 \%$ triton $\mathrm{X}-100$ minus the minimum fluorescence quenched by $350 \mathrm{mM} \mathrm{MnCl}_{2}(\mathbf{a}, \mathbf{c})$. Bars represent the mean $\pm \mathrm{SEM}$ of at least 4 independent experiments; $* P<0.05$, ** $P<0.01$, significantly different from sazetidine-A alone or in combination with PNU120596, non-paired one-way ANOVA, Bonferroni's multiple comparisons test

whereas preincubation with $10 \mu \mathrm{M}$ sazetidine-A resulted in a stronger block of $86 \%$. This effect was not due to run-down of responses or exhaustion of the $\mathrm{Ca}^{2+}$ indicator as responses recovered to 57 and $60 \%$ of control, respectively, after $10 \mathrm{~min}$ washout of sazetidine-A (Fig. 5).

\section{Discussion}

In this study we have exploited the PAM PNU-120596 to reveal activity of native $\alpha 7 \mathrm{nAChRs}$ [27], in order to examine the actions of sazetidine-A on $\alpha 7 \mathrm{nAChRs}$ expressed in SH-SY5Y cells and mouse cortical cultures. In the absence of the PAM, sazetidine-A evoked mecamylamine-sensitive increases in fluorescence in SH-SY5Y cells that were insensitive to MLA. The $\mathrm{EC}_{50}$ value of 
$4 \mu \mathrm{M}$ is consistent with the activation of human $\alpha 3 \beta 4 *$ nAChRs in SH-SY5Y cells; at heterologously expressed $\alpha 3 \beta 4$ nAChRs sazetidine-A is a relatively weak agonist, with efficacy ranging from $\sim 0$ to $100 \%$ in different studies, presumably reflecting differences in stoichiometry, species and methodology $[1,7,9]$.

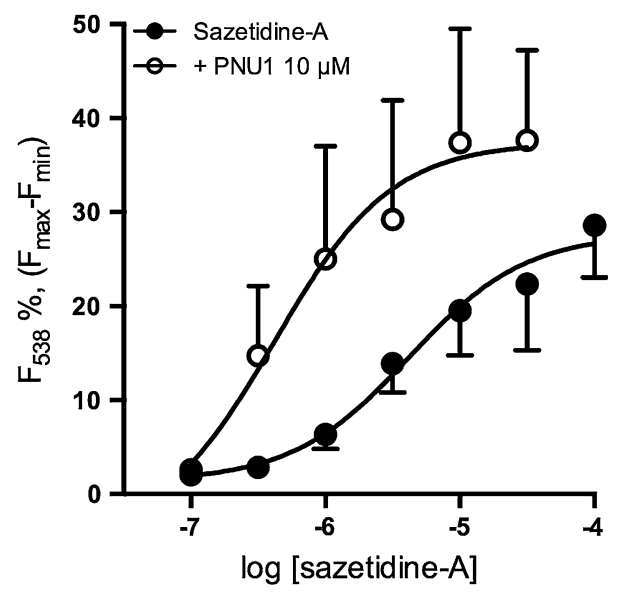

Fig. 2 Concentration dependence of sazetidine-A-evoked responses in SH-SY5Y cells. SH-SY5Y cells loaded with fluo-3 AM were stimulated with sazetidine-A $(0.1-100 \mu \mathrm{M})$ in the presence (solid black circles) or absence (open black circles) of PNU-120596 (PNU1; $10 \mu \mathrm{M})$. Fluorescence at $538 \mathrm{~nm}$ was measured for $20 \mathrm{~s}$ following stimulation with sazetidine-A. The increase in fluorescence at $20 \mathrm{~s}$ is presented as a percentage of the maximum fluorescence determined by addition of $0.2 \%$ triton $\mathrm{X}-100$ minus the minimum fluorescence quenched by $350 \mathrm{mM} \mathrm{MnCl} 2$. Points represent the mean $\pm \mathrm{SEM}$ from 8 independent experiments. Data were fitted to the Hill equation and $\mathrm{EC}_{50}$ values for sazatidine- $\mathrm{A}$ in the absence and presence of PNU-120596 were calculated to be 4.2 and $0.4 \mu \mathrm{M}$ respectively

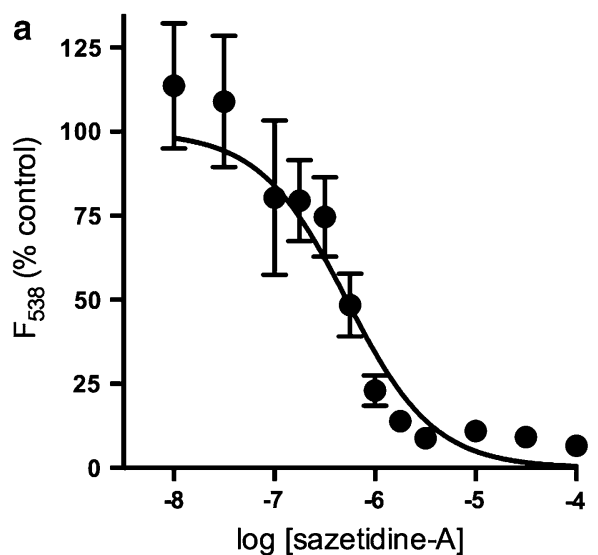

Fig. 3 Sazetidine-A inhibits responses evoked by nicotinic agonists in SH-SY5Y cells. SH-SY5Y cells loaded with fluo-3 AM and preincubated with sazetidine-A $(0.01-100 \mu \mathrm{M})$ for $10 \mathrm{~min}$ before stimulation with nicotine $(100 \mu \mathrm{M}$; solid circles, a) or PNU-282987 $(3 \mu \mathrm{M})$ together with PNU-120596 $(10 \mu \mathrm{M}$; open circles, b). The PAM was also present during the preincubation period in $\mathbf{b}$. Fluorescence at
The lack of $\alpha 7 \mathrm{nAChR}$ responses in the absence of the PAM is likely to reflect the rapid kinetics of the receptor, as other agonists were previously found to be without effect in this assay [24]. However, sazatidine-A was recently reported to activate rat $\alpha 7 \mathrm{nAChRs}$ with very low efficacy [14] although another study using a different assay and overexpressed human $\alpha 7 \mathrm{nAChRs}$, reported $100 \%$ efficacy [7]. The MLA-sensitive enhancement of responses to sazetidine-A in the presence of the PAM PNU-120596 is indicative of the recruitment of $\alpha 7$ nAChRs. The lower $\mathrm{EC}_{50}$ determined in the presence of PNU-120596 is likely to underestimate the true $\mathrm{EC}_{50}$ for sazetidine-A at $\alpha 7$ nAChRs as this PAM shifts the agonist concentrationresponse relationship to the left by approximately 0.8 of a $\log$ unit [25]. This suggests that the $\mathrm{EC}_{50}$ value for activation of $\alpha 7 \mathrm{nAChRs}$ in SH-SY5Y cells by sazetidine-A would be in the low $\mu \mathrm{M}$ range, comparable with the recent report that sazetidine-A activated recombinant $\alpha 7 \mathrm{nAChRs}$ in the absence of a PAM with an $\mathrm{EC}_{50}$ value of $1.2 \mu \mathrm{M}$, using a sensitive fluorescence assay to measure changes in membrane potential [7]. A higher $\mathrm{EC}_{50}$ value of $60 \mu \mathrm{M}$ was found using two-electrode voltage clamp recording from Xenopus oocytes expressing rat $\alpha 7 \mathrm{nAChRs}$ [14].The ability of a brief $(10 \mathrm{~min})$ incubation with sazetidine-A to ameliorate responses to subsequent stimulation of $\alpha 3^{*}$ or $\alpha 7 \mathrm{nAChRs}$ is consistent with its propensity to desensitize nAChRs. There was a concern that this experiment would be compromised by the requirement for preincubation with the PAM, alongside sazetidine-A, in order to reveal $\alpha 7$ nAChR-evoked responses. Although PNU-120596 prolongs the activation of $\alpha 7 \mathrm{nAChRs}$ [25], the duration of this effect is relatively short-lived with return to baseline within

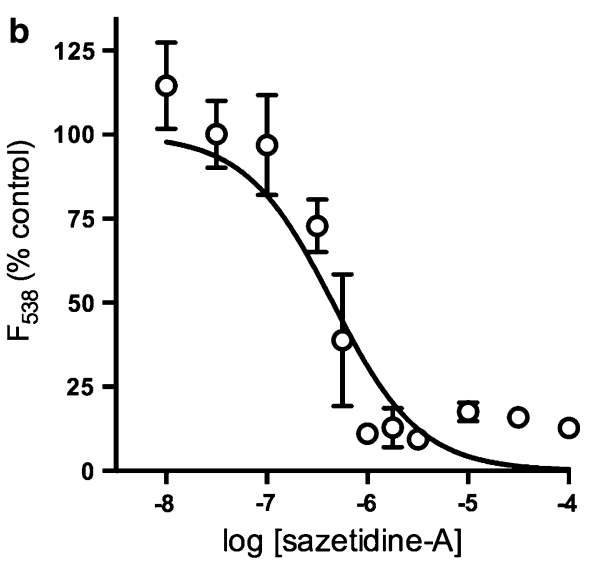

$538 \mathrm{~nm}$ was measured for $20 \mathrm{~s}$ following stimulation. Normalised responses at $20 \mathrm{~s}$ are expressed as a percentage of the response to agonist in the absence of sazetidine-A. Points represent mean \pm SEM of at least 4 independent experiments and are fitted to the Hill equation, yielding $\mathrm{IC}_{50}$ values of $522 \mathrm{nM}$ and $476 \mathrm{nM}$ for sazetidine-A versus nicotine and versus PNU-282987, respectively 


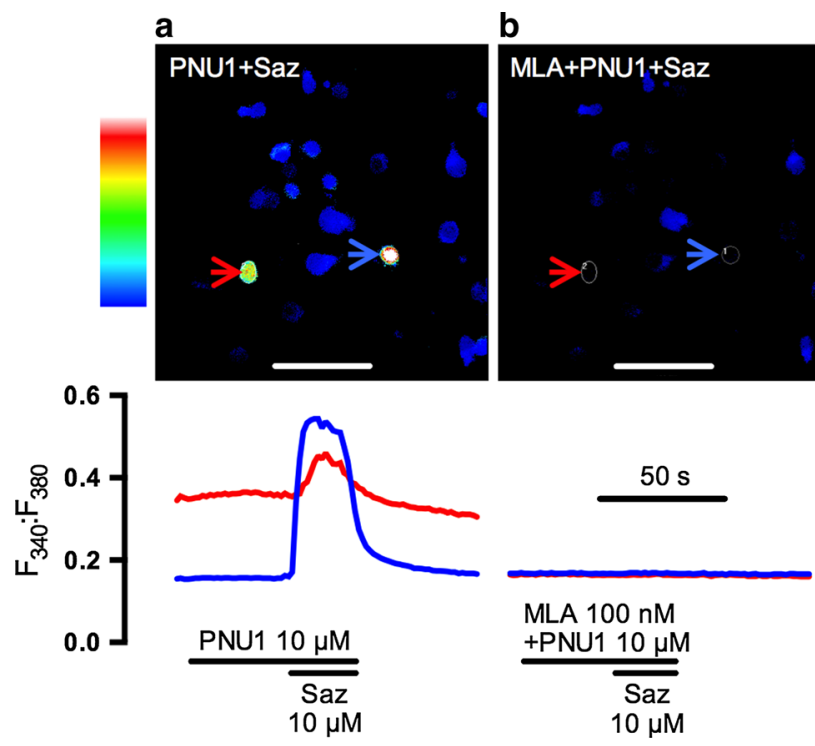

Fig. 4 Sazetidine-A elicits intracellular calcium elevations in the presence of PNU-120596 in mouse cortical cultures. Mouse E18 primary cortical cultures (10-14 DIV) were loaded with fura-2 AM, perfused with $1.8 \mathrm{mM}$ calcium buffer at $37{ }^{\circ} \mathrm{C}$ and imaged under a fluorescence microscope at $510 \mathrm{~nm}$. Cultures were pre-incubated with PNU-120596 (PNU1; $10 \mu \mathrm{M} ; 3 \mathrm{~min})$. Basal fluorescence $\left(\mathrm{F}_{340}: \mathrm{F}_{380}\right)$ was recorded for $30 \mathrm{~s}$ before stimulation with sazetidine-A (Saz; $10 \mu \mathrm{M} ; 20 \mathrm{~s}$ ). Following $3 \mathrm{~min}$ washout, cells were pre-incubated with MLA (100 nM; $10 \mathrm{~min})$ and PNU-120596 (10 $\mu \mathrm{M} ; 3 \mathrm{~min})$ prior to recording $\mathrm{F}_{340}: \mathrm{F}_{380}$ before, during and after co-stimulation with sazetidine-A (10 $\mu \mathrm{M} ; 20 \mathrm{~s})$. Following $10 \mathrm{~min}$ washout, the protocol was repeated in the absence of MLA. Panels a, b, c show representative images of the same field of cells taken during the 3 successive stimulations with sazetidine-A before, during and after

5 min [26]. The very similar inhibition curves for nicotineevoked responses in the absence of the PAM, attributed to $\alpha 3 \beta 4 *$ nAChRs, and for responses evoked by the $\alpha 7$ selective agonist PNU-282987 in the presence of PNU120596 argues that an inhibitory effect of sazetidine-A is measured in both cases and that $\alpha 3 \beta 4 *$ and $\alpha 7$ nAChRs are similarly sensitive to inhibition by sazetidine-A.

The $\mathrm{IC}_{50}$ values for this effect were $\sim 0.5 \mu \mathrm{M}$ (Fig. 3). This could be relevant to clinical applications of sazetidineA when therapeutic concentrations may approach these levels [28] (see below). Moreover, Campling et al. [7] recently highlighted 'smouldering activation' of nAChRs resulting from the balance within a population of receptors of sustained desensitization versus activation, such that the impact of chronic agonist concentrations will be complex.

The sensitivity of $\alpha 7 \mathrm{nAChRs}$ to sazetidine-A was reinforced by studies in primary cortical neurons. Interestingly, no changes in fluorescence were detected in response to sazetidine-A in the absence of the PAM. This was surprising as functional $\alpha 4 \beta 2 \mathrm{nAChRs}$ might have been anticipated to be present in cortical neurons. Possible explanations are that they are only present in the LS-
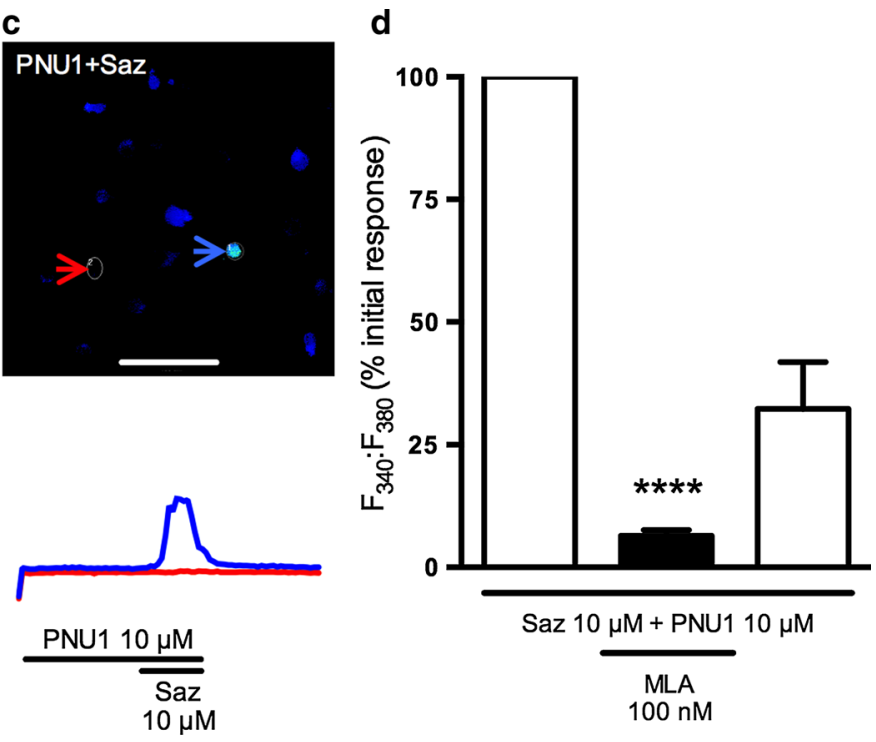

exposure to MLA; scale bar $150 \mu \mathrm{m}$. Fluorescence is shown in pseudocolour, $\quad\left(\right.$ black/blue $=$ low $\quad \mathrm{F}_{340}: \mathrm{F}_{380}, \quad$ red/white $=$ high $\mathrm{F}_{340}: \mathrm{F}_{380}$ ). Two cells that responded to stimulation in a representative experiment are indicated by the arrowheads and their individual fluorescence profiles are shown below; fluorescence changes are presented as a ratio of fluorescence emitted at $510 \mathrm{~nm}$ following excitation at 340 and $380 \mathrm{~nm}$. d Averaged data from 3 independent cultures are presented graphically. Bars represent the mean \pm SEM peak $\mathrm{F}_{340}: \mathrm{F}_{380}$ increase above basal, expressed as a percentage of the response to the initial stimulation with sazetidine-A in the presence of PNU-120596, from the same region of interest. $* * * * P<0.0001$ significantly different from initial response to sazetidine-A in combination with PNU-120596, one sample $t$-test

$\alpha 4_{3} \beta 2_{2}$ stoichiometry, or that they are absent at this developmental stage. Although $\alpha 4 \beta 2$ nAChRs have been documented on thalamocortical afferents [29], projection neurons would not be present in the cortical cultures. However $\alpha 4 \beta 2$ nAChRs may also occur on intrinsic cortical neurons [30, 31]. Alternatively, $\alpha 4 \beta 2 \mathrm{nAChRs} \mathrm{might}$ not initiate detectable changes in intracellular $\mathrm{Ca}^{2+}$, due to the presence of TTX in the perfusing buffer.

In contrast, in the presence of PNU-120596 sazetidine-A elicited robust responses from a minority of cells, estimated as $14 \%$ of the total population. This proportion is consistent with measurements using a selective $\alpha 7 \mathrm{nAChR}$ agonist together with the PAM (Brown and Wonnacott, unpublished observation). The almost total blockade of these responses by $100 \mathrm{nM}$ MLA confirmed that they arise from activation of $\alpha 7 \mathrm{nAChRs}$. Recovery following $3 \mathrm{~min}$ washout was partial and somewhat variable, possibly reflecting sazetidine-A's propensity to desensitize nAChRs. This was supported by the ability of sazetidine-A to produce a concentration-dependent-decrease in responses to PNU-282987, with sensitivity similar to that observed in SH-SY5Y cells. 


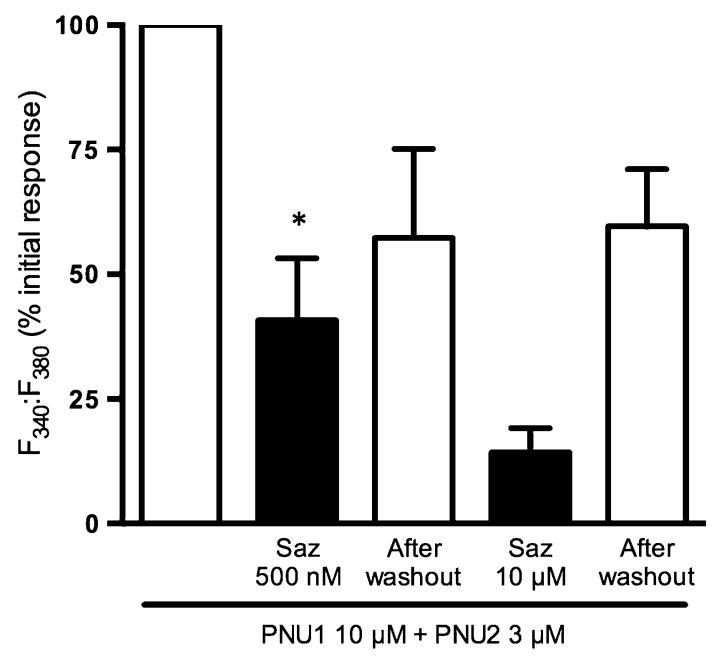

Fig. 5 Sazetidine-A attenuates responses to PNU-282987 in cortical cultures. Mouse E18 primary cortical cultures (10-14 DIV) were loaded with fura-2 AM, perfused with $1.8 \mathrm{mM}$ calcium buffer at $37{ }^{\circ} \mathrm{C}$ and imaged under a fluorescence microscope at $510 \mathrm{~nm}$. Cultures were pre-incubated with PNU-120596 (PNU1; $10 \mu \mathrm{M}$; $10 \mathrm{~min})$. Basal fluorescence $\left(\mathrm{F}_{340}: \mathrm{F}_{380}\right)$ was recorded for $30 \mathrm{~s}$ before during and after stimulation with PNU-282987 (PNU2; $3 \mu \mathrm{M} ; 20 \mathrm{~s}$ ). Following $3 \mathrm{~min}$ washout, cells were pre-incubated with sazetidine-A (Saz; $500 \mathrm{nM}$ or $10 \mu \mathrm{M})$ and PNU-120596 $(10 \mu \mathrm{M} ; 10 \mathrm{~min}$ ) prior to recording $\mathrm{F}_{340}: \mathrm{F}_{380}$ before, during and after stimulation with PNU$282987(3 \mu \mathrm{M} ; 20 \mathrm{~s})$. Following $10 \mathrm{~min}$ washout, the protocol was repeated in the absence of sazetidine-A. Responses are presented as a $\%$ of the initial response to PNU-282987, after subtraction of basal values. Bars represent the mean \pm SEM of data averaged from 3 (500 $\mathrm{nM}$ sazetidine-A) or $1(10 \mu \mathrm{M}$ sazetidine-A) independent cultures. $* P<0.05$ significantly different from initial response to PNU282987 in combination with PNU-120596, one sample $t$-test

Together these data provide evidence for the ability of low micromolar concentrations of sazetidine-A to activate native human and mouse $\alpha 7 \mathrm{nAChRs}$, whereas an inhibitory effect, likely reflecting desensitization of $\alpha 7 \mathrm{nAChRs}$, was observed at sub-micromolar concentrations of sazetidine-A. Brain concentrations of sazetidine-A administered chronically to rodents via osmotic minipump $(4.7 \mathrm{mg} / \mathrm{kg} /$ day) have been estimated to reach $32 \mathrm{nM}$, but repeated injection achieved transient levels that were 10 times higher [28]. This would be sufficient to elicit a degree of desensitization and/or 'smouldering activation' of $\alpha 7$ nAChRs [7], which could either compromise or contribute to the beneficial effects of a selective agonist such as sazetidine-A.

Acknowledgments This study was supported by a studentship to JLB from the Biological and Biotechnological Sciences Research Council (BBSRC). We are grateful to Pfizer for providing the PNU120596 and PNU-282987.

Ethical Standards The manuscript does not contain clinical studies or patient data. Standards of animal care were in accordance with the ARRIVE guidelines and UK law.
Conflict of interest The authors declare that they have no conflict of interest.

Open Access This article is distributed under the terms of the Creative Commons Attribution License which permits any use, distribution, and reproduction in any medium, provided the original author(s) and the source are credited.

\section{References}

1. Xiao Y, Fan H, Musachio JL, Wei Z-L, Chellappan SK, Kozikowski AP, Kellar KJ (2006) Sazetidine-A, a novel ligand that desensitizes alpha4beta2 nicotinic acetylcholine receptors without activating them. Mol Pharmacol 70:1454-1460

2. Zwart R, Carbone AL, Moroni M, Bermudez I, Mogg AJ, Folly EA, Broad LM, Williams AC, Zhang D, Ding C, Heinz BA, Sher E (2008) Sazetidine-A is a potent and selective agonist at native and recombinant alpha 4 beta 2 nicotinic acetylcholine receptors. Mol Phamacol 73:1838-1843. doi:10.1124/mol.108.045104

3. Carbone AL, Moroni M, Groot-Kormelink PJ, Bermudez I (2009) Pentameric concatenated (alpha4)(2)(beta2)(3) and (alpha4)(3)(beta2)(2) nicotinic acetylcholine receptors: subunit arrangement determines functional expression. Br J Pharmacol 156:970-981. doi:10.1111/j.1476-5381.2008.00104.x

4. Kuryatov A, Onksen J, Lindstrom J (2008) Roles of accessory subunits in alpha4beta2 $\left(^{*}\right)$ nicotinic receptors. Mol Pharmacol 74:132-143. doi:10.1124/mol.108.046789

5. Zhang J, Xiao YD, Jordan KG, Hammond PS, Van Dyke KM, Mazurov AA, Speake JD, Lippiello PM, James JW, Letchworth SR, Bencherif M, Hauser TA (2012) Analgesic effects mediated by neuronal nicotinic acetylcholine receptor agonists: correlation with desensitization of $\alpha 4 \beta 2 *$ receptors. Eur J Pharm Sci 47:813-823. doi:10.1016/j.ejps.2012.09.014

6. Kuryatov A, Lindstrom J (2011) Expression of functional human $\alpha 6 \beta 2 \beta 3^{*}$ acetylcholine receptors in Xenopus laevis oocytes achieved through subunit chimeras and concatamers. Mol Pharmacol 79:126-140. doi:10.1124/mol.110.066159

7. Campling BG, Kuryatov A, Lindstrom J (2013) Acute activation, desensitization and smoldering activation of human acetylcholine receptors. PLoS ONE 14(8):e79653. doi:10.1371/journal.pone. 0079653

8. Eaton JB, Lucero LM, Stratton H, Chang Y, Cooper JF, Lindstrom JM, Lukas RJ, Whiteaker P (2014) The unique $\alpha 4 \pm \alpha 4$ agonist binding site in $(\alpha 4) 3(\beta 2) 2$ subtype nicotinic acetylcholine receptors permits differential agonist desensitization pharmacology versus the $(\alpha 4) 2(\beta 2) 3$ subtype. J Pharmacol Exp Ther 348:46-58. doi:10.1124/jpet.113.208389

9. Liu Y, Richardson J, Tran T, Al-Muhtasib N, Xie T, Yenugonda VM, Sexton HG, Rezvani AH, Levin ED, Sahibzada N, Kellar KJ, Brown ML, Xiao Y, Paige M (2013) Chemistry and pharmacological studies of 3-alkoxy-2,5-disubstituted-pyridinyl compounds as novel selective $\alpha 4 \beta 2$ nicotinic acetylcholine receptor ligands that reduce alcohol intake in rats. J Med Chem 11(56):3000-3011. doi:10.1021/jm4000374

10. Johnson JE, Slade S, Wells C, Petro A, Sexton H, Rezvani AH, Brown ML, Paige MA, McDowell BE, Xiao Y, Kellar KJ, Levin ED (2012) Assessing the effects of chronic sazetidine-A delivery on nicotine self-administration in both male and female rats. Psychopharmacology 222:269-276. doi:10.1007/s00213-0122642-z

11. Rezvani AH, Cauley M, Sexton H, Xiao Y, Brown ML, Paige MA, McDowell BE, Kellar KJ, Levin ED (2012) Sazetidine-A, a selective $\alpha 4 \beta 2$ nicotinic acetylcholine receptor ligand: effects on dizocilpine and scopolamine-induced attentional impairments in 
female Sprague-Dawley rats. Psychopharmacology 215:621-630. doi:10.1007/s00213-010-2161-8

12. Alsharari SD, Carroll FI, McIntosh JM, Damaj MI (2012) The antinociceptive effects of nicotinic partial agonists varenicline and sazetidine-A in murine acute and tonic pain models. J Pharmacol Exp Ther 342:742-749. doi:10.1124/jpet.112.194506

13. Liu J, Yu LF, Eaton JB, Caldarone B, Cavino K, Ruiz C, Terry M, Fedolak A, Wang D, Ghavami A, Lowe DA, Brunner D, Lukas RJ, Kozikowski AP (2011) Discovery of isoxazole analogues of sazetidine-A as selective $\alpha 4 \beta 2$-nicotinic acetylcholine receptor partial agonists for the treatment of depression. J Med Chem 54:7280-7288. doi:10.1021/jm200855b

14. Zwart R, Strotton M, Ching J, Astles PC, Sher E (2014) Unique pharmacology of heteromeric $\alpha 7 \beta 2$ nicotinic acetylcholine receptors expressed in Xenopus laevis oocytes. Eur J Pharmacol 726C:77-86. doi:10.1016/j.ejphar.2014.01.031

15. Lendvai B, Kassai F, Szájli A, Némethy Z (2013) $\alpha 7$ nicotinic acetylcholine receptors and their role in cognition. Brain Res Bull 93:86-96. doi:10.1016/j.brainresbull.2012.11.003

16. Wallace TL, Bertrand D (2013) Importance of the nicotinic acetylcholine receptor system in the prefrontal cortex. Biochem Pharmacol 85:1713-1720. doi:10.1016/j.bcp.2013.04.001

17. Filippini P, Cesario A, Fini M, Locatelli F, Rutella S (2012) The Yin and Yang of non-neuronal $\alpha 7$-nicotinic receptors in inflammation and autoimmunity. Curr Drug Targets 13:644-655

18. Ridley DL, Pakkanen J, Wonnacott S (2002) Effects of chronic drug treatments on increases in intracellular calcium mediated by nicotinic acetylcholine receptors in SH-SY5Y cells. Br J Pharmacol 135:1051-1059

19. Hoey SE, Williams RJ, Perkinton MS (2009) Synaptic NMDA receptor activation stimulates alpha-secretase amyloid precursor protein processing and inhibits amyloid-beta production. J Neurosci 29:4442-4460. doi:10.1523/JNEUROSCI.6017-08.2009

20. Dajas-Bailador FA, Mogg AJ, Wonnacott S (2002) Intracellular $\mathrm{Ca} 2+$ signals evoked by stimulation of nicotinic acetylcholine receptors in SH-SY5Y cells: contribution of voltage-operated $\mathrm{Ca}^{2+}$ channels and $\mathrm{Ca}^{2+}$ stores. J Neurochem 81:606-614

21. Lukas RJ, Norman SA, Lucero L (1993) Characterization of Nnicotinic acetylcholine receptors expressed by cells of the SHSY5Y human neuroblastoma clonal line. Mol Cell Neurosci 4:1-12. doi:10.1006/mcne.1993.1001

22. Peng X, Katz M, Gerzanich V, Anand R, Lindstrom J (1994) Human alpha 7 acetylcholine receptor: cloning of the alpha 7 subunit from the SH-SY5Y cell line and determination of pharmacological properties of native receptors and functional alpha 7 homomers expressed in Xenopus oocytes. Mol Pharmacol $45: 546-554$
23. Riganti L, Matteoni C, Di Angelantonio S, Nistri A, Gaimarri A, Sparatore F, Canu-Boido C, Clementi F, Gotti C (2005) Longterm exposure to the new nicotinic antagonist 1,2-bisN-cytisinylethane upregulates nicotinic receptor subtypes of SH-SY5Y human neuroblastoma cells. Br J Pharmacol 146:1096-1109

24. Innocent $\mathrm{N}$, Livingstone $\mathrm{PD}$, Hone A, Kimura A, Young $\mathrm{T}$, Whiteaker P, McIntosh JM, Wonnacott S (2008) Alpha-conotoxin Arenatus IB[V11L, V16D] [corrected] is a potent and selective antagonist at rat and human native alpha7 nicotinic acetylcholine receptors. J Pharmacol Exp Ther 327:529-537. doi:10.1124/jpet.108.142943

25. Grønlien JH, Håkerud M, Ween H, Thorin-Hagene K, Briggs CA, Gopalakrishnan M, Malysz J (2007) Distinct profiles of alpha7 nAChR positive allosteric modulation revealed by structurally diverse chemotypes. Mol Pharmacol 72:715-724

26. Malysz J, Anderson DJ, Grønlien JH, Ji J, Bunnelle WH, Håkerud M, Thorin-Hagene K, Ween H, Helfrich R, Hu M, Gubbins E, Gopalakrishnan S, Puttfarcken PS, Briggs CA, Li J, Meyer MD, Dyhring T, Ahring PK, Nielsen EØ, Peters D, Timmermann DB, Gopalakrishnan M (2010) In vitro pharmacological characterization of a novel selective alpha7 neuronal nicotinic acetylcholine receptor agonist ABT-107. J Pharmacol Exp Ther 334:863-874. doi:10.1124/jpet.110.167072

27. Kalappa BI, Gusev AG, Uteshev VV (2010) Activation of functional $\alpha 7$-containing nAChRs in hippocampal CA1 pyramidal neurons by physiological levels of choline in the presence of PNU-120596. PLoS ONE 12(5):e13964. doi:10.1371/journal. pone. 0013964

28. Hussmann GP, Turner JR, Lomazzo E, Venkatesh R, Cousins V, Xiao Y, Yasuda RP, Wolfe BB, Perry DC, Rezvani AH, Levin ED, Blendy JA, Kellar KJ (2012) Chronic sazetidine-A at behaviorally active doses does not increase nicotinic cholinergic receptors in rodent brain. J Pharmacol Exp Ther 343:441-450. doi:10.1124/jpet.112.198085

29. Lambe EK, Picciotto MR, Aghajanian GK (2003) Nicotine induces glutamate release from thalamocortical terminals in prefrontal cortex. Neuropsychopharmacology 28:216-225

30. Aracri P, Amadeo A, Pasini ME, Fascio U, Becchetti A (2013) Regulation of glutamate release by heteromeric nicotinic receptors in layer $\mathrm{V}$ of the secondary motor region $(\mathrm{Fr} 2)$ in the dorsomedial shoulder of prefrontal cortex in mouse. Synapse 67:338-357. doi:10.1002/syn.21655

31. Poorthuis RB, Bloem B, Schak B, Wester J, de Kock CP, Mansvelder HD (2013) Layer-specific modulation of the prefrontal cortex by nicotinic acetylcholine receptors. Cereb Cortex 23:148-161. doi:10.1093/cercor/bhr390 